DOI: $10.22559 /$ folklor.1086

folklor/edebiyat, cilt: 25, sayı: 100, 2019/4

\title{
Geleneksel Ekolojik Bilgi ve Folklor
}

\section{Traditional Ecological Knowledge and Folklore}

\author{
Mehmet Ali Yolcu* \\ Mehmet Aça**
}

\begin{abstract}
$\ddot{\mathbf{O z}}$
Geleneksel ekolojik bilgi (GEB), uzun yıllardan sonra elde edilen ve insanın çevresiyle temasına dair deneyimlerle oluşmuş bilgi ve inançlar toplamıdır. Batı'da GEB'in terimleştirilmesi ve sürdürülebilir kaynak kullanımı ile ekolojik kalkınma hususunda modern topluma bir yol gösterebileceği fikri 1980'li yılların başından itibaren tartışılagelmiştir. Bu kavram, insan-doğa ilişkilerine dair sorunların temelini görmek açısından önemlidir. GEB araştırmaları, dünyanın birçok bölgesinde yaşayan yerel toplulukların her birinin çevresel uyarlanması sonucu özgün bir gelişme çizgisi göstermiş ekolojik bilgi birikimini gözler önüne sermesini amaçlamaktadır. Batı' daki GEB araştırmaları yaklaşık 40 yıldır devam etse de Türkiye'de terim literatüre yeni girmiştir. Farklı disiplinlerin ilgi alanına giren GEB araştırmalarının folklor disiplinindeki yeri ve önemi, GEB'le ilgili bir araştırma modeli oluşturmamızı gerektirmektedir. Bir topluluğa özgü GEB birikiminin nasıl toplanacağı, bu bilgiye hangi açılardan yaklaşılacağı ve nasıl analiz edileceği konuyla ilgili öncü çalışmalarla açıklığa kavuşturulabilir. Bu bağlamda çalışmamızda, kavramın tanımı, içeriği ve kapsamı, araştırmaların kısa tarihi ele alınarak folklorda GEB araştırma modeli önerilmiştir.
\end{abstract}

Anahtar sözcükler: geleneksel ekolojik bilgi, folklor, çevre etiği, sürdürülebilir kalkınma, araştırma modeli

* Doç. Dr., Çanakkale Onsekiz Mart Üniversitesi, Fen Edebiyat Fakültesi, Türk Dili ve Edebiyatı Bölümü, mehmetaliyolcu@comu.edu.tr. ORCID ID: 0000-0001-7688-287X.

** Prof. Dr., Marmara Üniversitesi, Fen Edebiyat Fakültesi, Türk Dili ve Edebiyatı Bölümü, mehmet.aca@ marmara.edu.tr.. ORCID ID: 0000-0003-3132-4086. 


\begin{abstract}
Traditional ecological knowledge (TEK) is a collection of knowledge and beliefs that have been acquired after many years of experience with human contact with the environment. In the West, the idea that TEK can guide the modern society in terms of terming and sustainable resource use and ecological development has been debated since the early 1980s. This concept is important to see the basis of the problems of human-nature relations. TEK research aims to reveal the ecological knowledge that has shown a unique development as a result of environmental adaptation of each of the local communities living in many regions of the world. Although TEK research has continued in the West for nearly 40 years the term has entered the literature in Turkey nowadays. The place and importance of TEK research in the field of folklore which is of interest to different disciplines requires us to form a research model about TEK. It can be clarified through pioneering studies on how TEK accumulation specific to a community will be collected, how to approach this information and how it will be analyzed. In our study, TEK research model in folklore was proposed by considering the definition, content and scope of the concept and brief history of the researches.
\end{abstract}

Keywords: traditional ecological knowledge, folklore, environmental ethics, sustainable development, research model

\title{
Giriş
}

İnsan, yeryüzünde görülmeye başladığı andan itibaren doğa ile etkileşime dayalı bir kültür oluşturmuştur. Bu kültür, kimi zaman doğaya egemenlik mücadelesinin bir şekli biçiminde görülürken kimi zaman da onunla uyumlu bir görünüm arz etmiştir. Bu bağlamda insan belirli noktalarda doğa tarafından yönlendirilmiş bir nesne, bazen de onu değiştirip dönüştüren bir özne olmuştur. Toplumsal düzenin yapısal yönünün kültürle mümkün hale gelmiş olduğu bilinmekle birlikte insan ve doğa ilişkisi çoklu anlamlara atıf yapan bir nosyonu da gerekli kılmaktadır. Bu ise, kültürde meydana gelen içsel ve dişsal dinamiklerin etkileşimini gösterebilecektir. İnsan ve doğa arasında bir akrabalık tasavvur eden geleneksel bilinç, bu tasavvuru sadece dünyayı tanıma ve benimseme açısından ihtiyaçları karşılama bağlamında ele almamıştır. Geleneksel bilinç; doğa ve insanı, başka bir deyişle makro-kozmos ile mikrokozmosu kendi içinde tutarlı bir özdeşlik üzerine inşa etmiş olup bu özdeşlik doğa ve insan uyumunu esas alan geleneksel kültürlerin oluşmasında da önemli bir yer tutmuştur.

Doğaya dair "geleneksel” ile "modern” bakış açısı arasındaki farklılıklar ilk etapta göze çarpan hususların başında gelmektedir. Nitekim ilk insan gruplarının doğaya dönük tasarımları, doğal nesnelere duyulan minnet veya korku gibi hislerle inşa ettiği animistik dünya görüşünün tezahürlerinin bir sonucudur. Doğa, insanlığın inançlarında ve kolektif vicdanında arketipsel formlar inşa etmeyi başarmış görünmektedir. Klan tipi örgütsel birliklerde primel atanın doğal dünyaya ait varlıklarla ilişkilendirilmesi, biyofiziksel bir varlık olarak insanın çevreyle olan ilişkilerinin spiritüel bir nitelikte olması, aslında uygarlığımızın ilk evrelerinde canlılar dünyasıyla insan ayrımının "doğanın içinde" kaldığına işaret etmektedir. Ancak, neolitik çağ ile başlayan ve endüstri çağıyla devam eden süreçte, mekanik bir düşünce sistematiğiyle insan zihninin doğayı bir "kaynak" olarak yapılandırmış olduğu görülmektedir. 
Endüstriyel üretimi deneyimlemiş modern toplumların dışında kalan geleneksel toplumlarda ve kabile tipi yerel gruplarda insanlığın ilk evrelerinde görülen doğaya dönük paradigmalara rastlamak, modern toplumların kronik ekolojik sorunlarına karşı geçmişi günümüze taşıyarak çözümler aramamıza kapı aralamıştır. Kimi çevrelerce insanlığın kurtuluş reçetesi olarak tanımlanan bu "doğaya dönüş" çabaları, akademik düzlemde yeni bir kavramın doğmasına ve bu kavram etrafında yeni perspektiflerin oluşmasına neden olmuştur. Sözünü ettiğimiz kavram, çevre etiğinin geleneksel köklerine ve doğa-insan ilişkilerindeki manevi motivasyonlara odaklanan "geleneksel ekolojik bilgi"dir.

Geleneksel ekolojik bilgi (GEB) insanların çevre ile ilişkisiyle bağlantılı, kuşaktan kuşağa aktarılan kümülatif bilgi, inanç ve uygulamalar olarak tanımlanabilir. Burada asıl olan topluluk içinde bilgi aktarımının sürekliliğidir. Bu kavram, insan-doğa ilişkilerine dair sorunların temelini görmek açısından önemlidir. GEB araştırmaları, dünyanın birçok bölgesinde yaşayan yerel toplulukların her birinin çevresel uyarlanması sonucu özgün bir gelişme çizgisi göstermiş ekolojik bilgi birikimini gözler önüne sermesini amaçlamaktadır. Bu noktadan hareketle endüstriyel ekonomiye dayalı modern toplumların doğayı istismar odaklı kalkınma stratejilerine alternatif bakış açıları üretilebilir. Geleneksel ekolojik bilgi birikiminin aktarımı; atasözleri, deyimler, kalıp ifadeler vb. dil malzemesi başta olmak üzere anlatılar, inançlar, ritüeller ve bunların toplamında önümüze çıkan geleneksel dünya görüşüyle mümkün hale gelmektedir.

Geleneksel toplumların tarım, ormancılık, avcılık ve hayvancılık faaliyetlerinde görülen çevre etiği geniş anlamda din, folklor ve arkaik inançlardan etkilenmiştir. Modern insanın neden olduğu çevre tahribatı, özellikle de orman veya ağaç kıyımı, ister istemez geleneksel bilincin doğayla ilgili tasavvurlarını da gündeme getirmiştir. Uygarlık, ilerleme, sanayi, teknoloji ve kaynak odaklı modern bilincin neden olduğu tahribat geleneksel çevre bilinciyle ilişkili GEB' in önemini arttırmış, geleneksel bilincin çevre ya da doğa bilincinin güncellenerek modern zamanlara aktarılması konusunu güncel hale getirmiştir.

GEB gerek bölgesel düzeyde gerek ulusal düzeyde topluluk üyelerine kişisel aidiyet ve anlamlar yükler. Bununla birlikte, hayatta kalma stratejilerinden biri olan çevresel uyarlanmada son derece etkin bir rol üstlenen GEB, biyo-çeşitliliğin korunması bağlamında da topluluklara geleneksel etik değerler sağlar. Nitekim Mazzocchi'nin de dikkat çektiği üzere (2006: 463), insan ve doğanın simbiyotik karakterini vurgulayan bir çevre kavramı geliştiren GEB, yerel kalkınmaya, çevre ile ortak evrime dayanan ve ekosistemlerin taşıma kapasitesine saygı gösteren bir yaklaşım sunar. Yerel koşullara adapte edilmiş uzun vadeli ampirik gözlemlere dayanan bu bilgi, çevrenin sağlıklı bir şekilde kullanılmasını ve kontrol edilmesini sağlar ve yerli halkın çevresel değişikliklere uyum sağlamasına olanak tanır. Ayrıca, temel ihtiyaçlarını karşılamak için dünya nüfusunun çoğuna imkânlar sağlar ve meteorolojik olayların yorumlanması, tıbbi arıtma, su kaynaklarının yönetimi, kıyafet üretimi, navigasyon gibi birçok pratik kararlar ve stratejiler için temel oluşturur. Tarım ve hayvancılık, avlanma ve balıkçılık ve biyolojik sınıflandırma sistemleri vb. tecrübeye dayalı bilgilere ihtiyaç duyan insanlar için bariz yararlarının ötesinde, insanlığa bir bütün olarak yeni biyolojik ve ekolojik anlayışlar sağlayabilir; doğal kaynakların yönetimi için potansiyel bir değeri vardır ve koruma eğitiminde olduğu kadar gelişim planlama ve çevre değerlendirmesinde de yararlı olabilir. 
Modern bilgi sistemleri, geleneksel olandan farklı olarak pozitivist temellere ve deneye dayalı edinim yollarına sahiptir. GEB ise klasik bilimin metodolojisinden farklı olarak bilgileri tasnifler ve tanımlar; GEB'e sahip topluluklar, onları çoklukla ruhsal ve kutsal zeminde öznel bir görüşle değerlendirir ve kuşaktan kuşağa sözlü olarak kesintisiz bir biçimde aktarır. Bilimsel ekolojik bilgi ile geleneksel ekolojik bilginin kavramsal çerçeveleri ve yöntemleri gibi hususlar bağlamındaki farklılıkları şöyledir: a. Geleneksel ekolojik bilgi, niteliğe; bilimsel ekolojik bilgi niceliğe odaklanmaktadır, b. Geleneksel ekolojik bilgi, sezgisel elementler barındırırken; bilimsel ekolojik bilgi aklın sınırları içinde işler, c. Geleneksel ekolojik bilgi, bütüncül bir bakış açısına sahipken; bilimsel ekolojik bilginin bakışı indirgemecidir, d. Geleneksel ekolojik bilgi, zihni ve maddeyi birlikte düşünürken; bilimsel ekolojik bilgi bunların ayrılması yönünde bir tavır içindedir, e. Geleneksel ekolojik bilgi, bilimsel ekolojik bilginin aksine ahlakçıdır; değer yargılarından arınma gibi bir eğilim içinde değildir, f. Bilimsel ekolojik bilgi mekanik işleyişi önemserken; geleneksel ekolojik bilgi ruhsallığı ön planda tutmaktadır, g. Geleneksel ekolojik bilgi ampirik gözleme ve gerçeklerin deneme-yanılma yöntemiyle elde edilmesine dayalı iken; bilimsel ekolojik bilgi gerçeğin sistematik bir bilinçle ve deneyle elde edilmesinden yanadır, h. Geleneksel ekolojik bilgi, ekolojik kaynakları kullananların tecrübeye dayalı verilerine dayanırken; bilimsel ekolojik bilgi uzmanlaşmış araştırmacı grupların verilerine değer verir, 1. Geleneksel ekolojik bilgi, artzamanlı verilere dayanırken, yani derin tarihsel süreçleri önemserken; eşzamanlı verilere önem veren bilimsel ekolojik bilgi tespitte bulunmak için kısa zaman aralıklarını yeterli görmektedir (Aça, 2016a: 431-432; Berkes, 1993: 1-5).

\section{GEB araştırmalarının kısa tarihi}

GEB araştırmaları, daha eski tarihlerde başlamış olsa da GEB terminolojisinin kullanımı 1980'li yıllara kadar geri götürülebilir. GEB'in kullanımı ise insanlığın avcı-toplayıcı dönemleri kadar eskidir (Berkes, 1993: 1; Berkes, 2008: 2). "Ekolojik antropoloji”, “derin ekoloji”, “çevresel determinizm” gibi kavramlar çerçevesinde yapılan çalışmalar elbette yerel kültürler ve çevre ilişkilerinde manevi ögelere odaklanmıştır, ancak sistematik GEB araştırmaları ekosistemin bir parçası olan insana projeksiyon tutarak geçimlik ekonomik modellere dayalı geleneksel toplumlardaki yerel çevre bilgisinin çeşitli kollarında yoğunlaşmıştır. $\mathrm{Bu}$ yerel bilgi sistemi; geçim teknolojileri, geleneksel tıp, etnobotanik, su kaynaklarının kullanımı gibi çok farklı uygulama sahaları bulabilmektedir. Berkes'in (1993: 3) de ifade ettiği gibi, ekolojiye ek olarak; tarımda, farmakoloji ve botanikte zengin bir geçmişi olan geleneksel bilgi çalışmaları birçok farklı alanda değerlendirilmektedir. Aslında, bu alanlara kıyasla, ekolojideki yerli bilginin incelenmesi nispeten yenidir.

GEB ile ilgili ilk sistematik çalışmalar antropologlar tarafından yapılmıştır. Etnolojinin bir alt kümesi olarak tanımlanabilen etno-ekoloji (belli insanların ya da kültürlerin ekolojik ilişkiler hakkındaki düşünce yapısına odaklanan yaklaşım) kapsamındaki ekolojik bilgi çalışmaları, Hardesty (1977) tarafından söz konusu olan kültürün objeleri, aktiviteleri ve evrendeki olayları sınıflandırmak için oluşturduğu bilgi sistemlerini inceleyen bir çalışma olarak tanımlanmıştır. Ekolojik bilgi Levi-Strauss'un dediği gibi doğal çevrenin yerel varlıklarca bilgisidir. Diğer yandan Levi-Strauss'a göre (2010) ekoloji, doğal çevrenin yerel varlıklarca anlaşılmasından hareketle ilkel düşüncenin de kaynaklarından biridir. Bu bağlamda GEB'le 
ilişkili yapılan büyük çalışmalarda (örneğin Lasserre ve Ruddle, 1982; Ruddle ve Johannes, 1989; Freeman ve Carybn, 1988) GEB'in farklı anlamları ve unsurlarına yapılan vurgular bu alanda öncü rol oynamışlardır. Berkes'in verdiği bilgilere göre (1993: 2), GEB ile ilgili kitap hacmindeki çalışmalar; GEB'in aktarımı (Ruddle ve Chesterfield, 1977), topluma dayalı GEB araştırma yaklaşımları (Johnson, 1992), GEB'in gelişime uygulanması (Brokensha vd., 1980) ve kaynak yönetimi (Klee, 1980), Okyanusya'da balıkçıların GEB sisteminin detaylı biyolojik/ekolojik değerlendirmesi (Johannes, 1981), geleneksel koruma (Moruata vd., 1982; Mc Neely ve Pitt, 1985), geleneksel kıyı kaynaklarını yönetim sistemleri (Lasserre ve Ruddle, 1983), kuzey ekosistemlerinin GEB'i (Freeman ve Carbyn, 1988), kurak alan ekosistemleri (Niamir, 1990) ve tropik orman ekosistemleri (Posey ve Balee, 1989), çevre felsefesi ve yerel bilgi (Knutdson ve Suzuki, 1992) ve Asya ve Pasifik'te geleneksel deniz kaynaklarını yönetme sistemleri (Ruddle ve Johannes, 1989) gibi farklı konuların GEB çatısı altında ele alınmalarını içerir. Aslında Batı'da 2000'li yıllardan sonra GEB çalışmalarının farklı disiplinler altında oldukça arttığını söyleyebiliriz.

Konuya dair uluslararası ilgi, akademik ortamın dışında hukuki-politik alana da yansımıştır. 1992 yılında BM nezdinde Biyolojik Çeşitlilik Sözleşmesi (CBD) kabul edilmiş olup 1996 yılında Türkiye bu sözleşmeye taraf olmuştur. Sözleşmede, geleneksel/yerel bilginin önemine vurgu yapılmış ve bu bilginin saygı görmesi ve korunması hususunda görüşler ortaya konmuştur. Dünya Fikri Mülkiyet Örgütü (WIPO), Biyolojik Çeşitlilik Sözleşmesi’ne taraf devletlerin talebiyle 2000 yılında "Fikri Mülkiyet ve Genetik Kaynaklar, Geleneksel Bilgi ve Folklor (IGC) Hükümetlerarası Komitesi”ni kurmuştur. Bu komite 2019 yılı itibariyle 40. toplantısını gerçekleştirmiş bulunmaktadır. Uluslararası girişimlere rağmen Türk hukuk mevzuatında ise hem yerel bilgi hem de GEB'e yönelik hükümler henüz yoktur. Özgür Semiz'in verdiği bilgilere göre (2013: 388-389) bu bilgi, serbestçe kullanılabilmekte, belli yöreye özgü geleneksel kültürel ifadeler, ticari amaçlı ürünler üzerinde yer alabilmekte; müzik, sinema ve güzel sanat eserleri gibi telif haklarına konu eserlerin üretiminde girdi olabilmekte, sınai haklar alanında örneğin geleneksel tedavide kullanılan bitki bileşimleri ve tedavi yöntemleri, patent korumasına haiz modern ilaç, tıbbi ürün ve uygulamaların yaratılmasında girdi olarak işlenebilmektedir. Özdemir'in konuya dair değerlendirmelerine göre (2018: 22), WIPO geleneksel bilgi, genetik kaynaklar ve folklorun geleneksel kültürel ifadeleri ile ilgili olarak sunulan farklı bakış açılarını ve çözüm önerileri değerlendirerek ülkelerin kendilerine özgü koruma politikalarını, yasalarını, bilgi sistemlerini ve uygulama araçlarını geliştirmelerine katkı sağlamaktadır. Türkiye'de de bu kapsamda uygun bir modelin yaratılması ve uygulanması mümkün olabilir.

Türkçe literatürde GEB terimini ilk kullanan Türk kökenli ABD'li bilim insanı Fikret Berkes’tir (1993). Türkiye'de ise bu terimin literatüre girmesi oldukça yenidir. Ankara Üniversitesi Sosyal Çevre Bilimleri Anabilim Dalı'nda Ferhat Büyükşahin tarafından Sarıkeçili Yörüklerinin GEB'i üzerine yazılan doktora tezi (2017), bu tezden üretilen bir makale (Büyükşahin ve Güneş, 2016) ve pastoral topluluklardaki kültürel peyzaj konusunda yazılmış bir makale (Büyükşahin ve Güneş, 2017) doğrudan GEB'i kapsayan çalışmalardır. Halk bilimi disiplininde ise konuya ilk temas eden ve Karadeniz kıyı balıkçılarının GEB'ini ele alan bilim insanı Mustafa Aça'dır (2016b). Ardından 2018 yılında Çanakkale halk botaniği ile GEB ilişkisine dair bir makale de Mehmet Ali Yolcu tarafından yazılmıştır (2018). 
Yine 2018 yılında Nebi Özdemir'in kaleme aldığı “Geleneksel Bilgi ve Kültür Ekonomisi” başlıklı makalesi de "geleneksel bilgi” kavramının tanıtılması, WIPO’ya bağlı komitenin bakış açısı ve geleneksel bilginin kültür ekonomisine kazandırılmasına dönük tespitleriyle dikkat çekicidir. Yine aynı yıl, Ankara Üniversitesi Sosyal Bilimler Enstitüsü Halkbilim Anabilim Dalı'nda Karabaşa'nın (2018) yazdığı doktora tezi, Ankara'da bir köy özelinde kültürçevre ilişkisine odaklanması ve böylece "ekolojik folklor” çalışmalarında öncü rol oynaması bakımından önemlidir. Karabaşa, tezinde GEB'den de söz etmiştir. Burada kısaca temas ettiğimiz çalışmalardan da anlaşılacağı üzere, GEB ile ilgili Türkçe veya Türkiye kaynaklı literatür yok denecek kadar azdır. Batı akademisinde 1980'li yıllardan itibaren yapılmaya başlanan GEB çalışmalarının ülkemizde yaklaşık 40 yıl sonra dikkat çekmeye başladığını söylemek mümkündür. Bununla birlikte son bir iki yıl içinde ülkemizde bu kavramı temel alan çalışmaların arttı̆̆ı da gözlemlenmektedir.

\section{Folklorda GEB ve bir araştırma modeli}

GEB, çoğu zaman açıkça kendini göstermese de topluluk üyelerinin geleneklerinde, ritüellerinde ve inançlarında gömülü bir formdadır ve araştırmacılarca keşfedilmeyi beklemektedir. Bu durum aynı zamanda folklordaki geleneksel bilgi depolarında GEB'in ortaya çıkartılması anlamına da gelmektedir. Folklorun bir parçası olarak kabul gören inançlar ve bilgiler, ekolojiye dair tutum ve davranışlar üzerinde etkili bir role sahiptir. Folklor, doğası gereği kolektif bilinci bünyesinde barındırdığından bir topluluğun hafızasında yer alan GEB, aynı zamanda kolektif bilinç ve tutumların yansıması olarak da tezahür etmektedir. Ekolojik ahlakın topluluğa özgü yönleri, GEB mirasının bütüncül bir tarzda araştırılmasıyla ortaya çıkartılabilir. Örneğin Şamanist veya pagan topluluklarda görülen doğa kavrayışı ile tek-tanrıcı klasik dinlerin egemenliğindeki topluluklarda karşımıza çıkan doğa kavrayışı birbiriyle örtüşmemektedir. İlk grupta doğa, ruhani yönleriyle ve insanla etkileşime dayalı boyutuyla görünüm kazanmışken ikincisinde doğa insanın hizmetine sunulmuş ve daha aşağı veya insanın dâhil olmadığı bir kategoride değerlendirilmiş biçimiyle kurgulanmıştır. Folklorda izini sürdügümüz Türk geleneksel dünya görüşünü besleyen ana perspektiflerden biri de animizm, totemizm ve Şamanizm kaynaklı mitolojik-arkaik bir doğa bilgisidir. Bu bağlamda, Türk folklorunun en eski formlarında canlılar dünyası ile insan arasında keskin bir hiyerarşinin kabul edilmediği ve bundan hareketle doğa-kültür karşıtlığı olgusunun yerine doğa-kültür bütünlüğünün görünür kılındığı söylenebilir.

Yine, folklorda yaşayan birtakım inanış, uygulama ve kabuller, yaşadığı bölgede toplulukların çevreyle ve doğal dünyayla ilişkilerini inşa etmektedir. Aça'ya göre (2016a: 559), geleneksel dünya görüşünün yansımaları niteliği taşıyan halk bilgisi kadroları çoğu zaman geleneksel nitelikler taşıyan köklü bir ekolojik bilgi birikimiyle yakından ilgilidir. Bir kültür veya yerel topluma ait, bu kültür ve sosyal yapı kapsamında hayatın içinden elde edilmiş yerel bilgi, doğayla iç içe yaşayan halklarda daha fazla gözlenir. Yerel bilgi kapsamında değerlendirilen hususlar, gelenek ve göreneklerde, halk meteorolojisinde, halk tıbbında, halk mutfağında vb. kendini gösterir. Bununla birlikte GEB, durağan bir bilgi değildir, kuşaktan kuşağa aktarıma sahip devingen bir yapıya sahiptir. Araştırmacılar tarafından geniş bir disiplin yelpazesinden elde edilen geçim ekonomili topluluklar hakkındaki veriler, GEB'in akta- 
rılmasının bazı yapısal ve süreçsel özellikleri hakkında oldukça tutarlı genellemeler sağlar. Ruddle (1993: 18), bunları şöyle özetlemiştir: 1. Ekonomik faaliyetlerde görev eğitimi için belirli yaş bölümleri vardır. 2. Farklı görevler yetişkinler tarafından benzer ve sistematik bir şekilde öğretilir. 3. Belirli bir görev kompleksi içinde bireysel görevler, basitten karmaşığa kadar değişen bir sıra ile öğretilir. 4. Görevler cinsiyete ve yaşa özeldir ve uygun cinsiyetin üyeleri tarafından öğretilir. 5. Görevler bölgeye özgüdür ve gerçekleştirilecekleri yerlerin tiplerine göre öğretilir. 6. Sabit dönemler özellikle öğretim için ayrılır. 7. Görevler, genellikle öğrencinin ebeveynlerinden biri olan belirli akrabalar tarafından verilmektedir. 8. Bir ödül veya ceza şekli, belirli görevler veya görev kompleksleriyle ilişkilendirilir.

Toplumsal yasaklar ve tabular ile ekolojinin korunması arasında bir ilişki vardır. Folklorun bir parçası olan tabu ve kaçınma davranışlarının ekolojik korumaya dolaylı yoldan olumlu etkilerinden söz edebiliriz. Örneğin, doğadan çokça uzaklaşmamış topluluklarda daha fazla görülen tabiat kültleri temelli inançlar, belirli bölgelerin, su kaynaklarının, ormanların kirletilmemesi veya o bölgelerdeki doğal ürünlerin aşırı tüketimini engellemesi açısından yararlıdır. Yine, bazı hayvanlarla ilgili inançlar o hayvan türlerinin avlanılmasını yasaklamaktadır ve böylece söz konusu hayvan türlerinin yok olma tehdidi altında kalmasının önüne geçilmektedir. Bu da aslında doğadaki besin zincirinin bozulmaması açısından önemlidir. Frazer'ın batıl inançlar kapsamında ele aldığı tabu ve kaçınma davranışları (Frazer 2017; Frazer, 2019), çoğunlukla irrasyonel düşüncenin ürünü olarak nitelendirilmekle birlikte insanlığın varlığını doğayla uyumlu ve dengeli bir şekilde sürdürmesinde etkili olmuştur. Hayatını ormandan ağaç keserek sürdürmek zorunda olan geleneksel insanın ormanın ruhu ya da iyesine bağlı tabu ve kaçınma davranışları ile taygada avlanmak zorunda olan geleneksel avcının tayga iyesi ya da hayvan ruhlarına bağlı tabu ve kaçınma davranışları, her ne kadar rasyonel düşünce ile tek tanrılı dinler tarafından akıl ve iman dışı olarak nitelendirilmiş olsalar da insanı sınırlandırarak doğaya ağır zararlar vermesinin önüne geçmiştir. Hayatını avlanarak devam ettirmek zorunda olan geleneksel avcının av hayvanları ile olan uyum ve denge üzerine kurulu ilişkileri ile günümüzün avlanmak zorunda olmayan, fakat sırf rahatlamak ve eğlenmek için onlarca kekliği öldüren ve öldürdüğ̈̈ onlarca kekliğin başucunda bir kahraman edasıyla fotoğraf çektiren modern insanın hayvanlarla olan ilişkisi arasında bariz bir farklılık vardır.

Pastoral nitelikli kolektif yaşam biçimlerinde sıkça karşılaştığımız doğaya uyumu destekleyen GEB, sezgisel arka planıyla sürdürülebilir geçimlik ekonomik modeller için son derece kullanışlıdır. Örneğin, geleneksel kara avcılığı ve balıkçılığa dair bilgi ile ticari yönleri olan modern avcılık ve balıkçılık bilgisi arasında farklar vardır. Geleneksel olan faaliyetler maneviyata dayalı otokontrole sahipken diğeri yalnızca hukuki sınırlandırmalara tabidir. Yani GEB'e bağlı çevre etiği, geleneksel bilinçle aktarılmakta olduğundan geleneksel bilgiye sahip bireyler kendiliğinden ekolojiye duyarlı haldedirler. Bu bağlamda Türkiye'de henüz gelişme aşamasında olan meslek folkloru çalışmaları, GEB eksenli bir şekilde yapıldı̆̆ takdirde tarıma, bahçeciliğe, hayvancılığa, balıkçılığa ve arıcılığa bağlı geleneksel bilgiyle uygulamaların çok daha ayrıntılı bir şekilde öğrenilmesini ve bunların modern hayata yeniden kazandırılmasını sağlayacaktır.

GEB'in büyük kısmının ekolojik korumaya olumlu katkılar sağladığını söylemek mümkünse de bazı inanç ve tutumlar belirli hayvan türlerine dair önyargıları beslemeye devam et- 
mektedir. Örneğin, kertenkele ve kaplumbağaların siğile neden olduğuna dair önyarg1 (Ceriaco vd., 2011), domuzun lanetli bir hayvan olarak kabulü, yılanlar hakkında olumsuz duygular bu türlerin tehdit altında olmasına yol açabilmektedir. Öyle anlaşılıyor ki, GEB tümüyle ekolojik korumaya pozitif bir katkı sağlamamaktadır. Bu durumda canlı türlerine karşı konumlanmış antroposantrik olumsuz inançlar söz konusu olduğunda modern eğitim sistemi devreye girerek bu hususa karşı önlemler alabilmelidir. İnsanlar, eğer canlıları ve toprağı doğal dünyalarının ayrılmaz bir parçası olarak görürlerse bazı yollarla onları koruma altına alabilir.

GEB çalışmaları dolaylı olarak biyoloji, botanik, zooloji, coğrafya, farmakoloji, çevre felsefesi, çevre bilimleri, antropoloji gibi disiplinler tarafindan yürütülebilmektedir. Ancak tüm bu saydığımız disiplinlerde GEB'in belirli bir bölümü ele alınmaktadır. Folklor ise, disiplinin doğası gereği GEB'e bütüncül yaklaşmak durumundadır. GEB'e yönelik bir folklor çalışmasından ilk olarak GEB'in arka planına dair analizlerle birlikte olguyla ilişkili unsurları envanterleme, GEB'e dayalı kültürel mirasın tespiti ve buradan çıkarılacak yaygın etkilerin ele alınması beklenmektedir. GEB'e doğrudan yönelen folklor çalışmalarında, GEB'in insanın canlılar dünyasıyla ilişkilerinde, ürettiği simgelerde, nesne kullanımı ve davranışlarında nasıl ortaya çıktığını anlamak, ekolojiyle ilişkili kültürel kod ve örüntülerin toplulukların yapısal işleyişine etkisini saptamak, daha genel anlamda toplulukların dünya görüşlerinin biçimlendirdiği GEB' in folklorik kaynaklarını belirlemek vb. amaçlar gütmek GEB'in daha doğru anlaşılması açısından faydalı olacaktır. Ayrıca, GEB'in toplumsal yapıyı etkileyen işlevleri irdelenerek kültürel kodlarla inşa edilmiş ekolojiye dönük stereotiplerin toplumun inanç ve düşünce dünyasına etkisine odaklanmak da metodolojik açıdan çalışana birtakım kolaylıklar sağlayabilir.

Folklor ve GEB ilişkisini çözümlemek isteyen bir araştırmacı, GEB unsurlarını nasıl tespit edecek ve sınırlandıracaktır? Bu hususta 13 maddelik bir tasnif önermekteyiz ki bu tasnif geliştirilmeye de açıktır: 1. Doğayla uyumlu halk mimarisi ve bu mimari tarzında kullanılan doğal ürünler; gündelik hayatta kullanılan doğal nesneler. 2. Geleneksel hayvancılık ve halk zoolojisi (sığır, keçi, koyun çobanlığı etrafında gelişen geleneksel bilgi başta olmak üzere halk baytarlığı ile hayvansal ürünlerin üretimi, muhafazası, pazarlanması ve tüketimi aşamaları vb.). 3. Geleneksel tarım ve halk botaniği (Tarımsal ürünler ve doğal bitki dünyasına dair inanç ve uygulamalar, geleneksel peyzaj, bu konu etrafında oluşmuş halk meteorolojisi ve halk takvimi, doğadan toplanan ürünlerin tüketimi vb.). 4. Halk hekimliğinde kullanılan bitkisel/hayvansal ürünler ve bunların etrafında oluşan büyüsel/dinsel inançlar. 5. Halk mutfağ 1 ekseninde yiyeceklerin pişirilme ve saklanma teknikleri. 6. Toprağa, meralara ve hayvan mülkiyetine bağlı gelişen halk hukuku. 7. Çevrenin korunmasında ve kutsallaştırılmasında türbe, mezar, ziyaret yeri vb.nin rolü. 8. Geleneksel avcılık ve balıkçılık (karasal ve sucul alanlardaki av hayvanları ve avcılığa dair süreçler, teknikler, inançlar ve uygulamalar). 9. Bereketi artırmaya dönük yapılan ritüeller ve seyirlik temsiller. 10. GEB ile ilişkili uygulamalı halk bilimi. 11. GEB ekseninde oluşan dil malzemesiyle birlikte halk edebiyatı birikimi. 12. Doğal ürünlerden yapılma çocuk oyuncakları. 13. Geleneksel dünya görüşü odağında insandoğa ilişkisine atıflar yapan diğer inanış, kabul ve uygulamalar.

Yukarıdaki maddeleri içeren bir GEB araştırması kapsamında bir yörenin GEB envanteri hazırlanırken aşağıda tablolaştırdığımız biçimiyle veri toplanması mümkündür: 
Tablo 1: GEB Unsuru Envanterleme Tablosu

\begin{tabular}{|c|c|}
\hline \multicolumn{2}{|c|}{$\begin{array}{c}\text { GEB Unsuru (GEBU) } \\
\text { (Ad1 ve Numaras1) }\end{array}$} \\
\hline GEBU Tipi & $\begin{array}{l}\text { Nesne }(\mathrm{N}) \text {, varlık }(\mathrm{V}) \text {, sanatsal model } \\
(\mathrm{SM}) \text {, süreç }(\mathrm{S}) \text {, inovasyon (I) (Kısaltma- } \\
\text { lar envanter tablolarına uygun hale geti- } \\
\text { rilebilir) }\end{array}$ \\
\hline $\begin{array}{l}\text { GEBU'nun yöresel adlandırma ve çeşit- } \\
\text { lenmeleri; GEBU'yla ilgili dil birikimi }\end{array}$ & \\
\hline GEBU'nun yöresel kullanım amaçları & \\
\hline GEBU'nun yöresel kullanım yöntemleri & \\
\hline $\begin{array}{l}\text { GEBU'nun ritüelistik yönü, GEBU'yla } \\
\text { ilgili inançlar, tabu/kaçınmalar, kabuller }\end{array}$ & \\
\hline GEBU'nun coğrafi dağılımı & \\
\hline
\end{tabular}

Yukarıdaki tablodan da anlaşılacağı üzere GEB birikimine dair unsurlar, "nesne”, "varlık", "sanatsal model”, "süreç" ve "inovasyon” olmak üzere beş tipte tasnif edilmiştir. Bir unsurun keskin sınırlarla ayrılamayacak özellikleri söz konusu olduğunda birden fazla tip işaretlenerek unsur envantere kaydedilebilir. Ardından GEB unsurunun yöresel kullanım amaçları ve yöntemleri hakkında bilgi verilir. Burada kolektif veya bireysel amaç ve yöntem ayrımına gidilebilir. GEB unsurunun ritüelistik yönü, buna dair inançlar, tabu/kaçınmalar ve kabuller detaylandırılarak GEB'in manevi alanına dönük değerlendirmeler için alt yapı hazırlanmalıdır. Son olarak GEB unsurunun araştırma evren ve örneklem bölgesindeki coğrafi dağılımı, yerleşim birimlerinin adları yazılarak gösterilebilir.

\section{Sonuç}

GEB, uluslararası literatürde "geleneksel bilgi" veya "yerel bilgi” olarak adlandırılan kavramın bir bileşenidir. Folklorun çalışma alanları, geleneksel bilgi üzerine inşa edilmiş olduğundan GEB ile folklor korelasyonu net bir biçimde karşımızda durmaktadır. GEB'in çeşitli öğelerinin derlenmesi, kayıt altına alınıp arşivlenmesi ve böylece çeşitli ülkelerde örneklerini gördüğümüz GEB veri tabanı oluşturulması için hem bireysel çabalara hem de devlet organları öncülüğüyle yapılacak sistematik ve uzun soluklu çalışmalara ihtiyaç vardır. Buradan hareketle belirli stratejik planlar dahilinde topluluklara yeni ekolojik üretim sahaları, pazarlama ve tüketim alışkanlıkları kazandırılabilir. Diğer yandan GEB'in patentleme ve telif yolu ya da sui generis korunmasına dair tartışmalar da uzunca bir süre konuyla ilgilenen akademisyenleri meşgul edecek gibi durmaktadır.

Modern toplumun kalkınma stratejilerinden vazgeçmesi söz konusu değildir ve bu husus toplumların uluslararası sözleşmelerle korunan hakkıdır. Ancak sürece dair bilimsel müdahalelerimiz, modernizasyon süreçlerinde insan-çevre ilişkilerini daha sağlıklı bir zemine 
oturtmayı amaçlamalı ve böylece doğayla barışık sürdürülebilir kalkınma ile geleneksel ekolojik kaynak yönetimi ilişkilendirilmelidir. GEB'in sarmal bir biçimde inşa ettiği, toplumda karşılık bulan doğaya dair postülatlar ortaya konarak ekolojiyle uyumlu halk bilgisi çözümlenirse, bunun son yıllarda söylem olarak sıkça kullanılan alternatif yaşam, ekolojik turizm, sağlıklı ve doğal beslenme, doğaya uyumlu mimari vb. yönelimlere düşünsel bir altyapı sağlayıp sağlamayacağı da anlaşılacaktır. Ancak bu çabalar, kapitalist model içinde doğanın "pazarlanması"na yönelik endişeler de dikkate alınırsa anlamlı hale gelecektir. Şu bir gerçek ki, GEB, 21. yüzyıl yaşam tarzlarında insanlığa yeni ekolojik perspektifler kazandıracak potansiyeli taşımakta ve folklorcular tarafından araştırılmayı beklemektedir.

\section{Kaynaklar}

Aça, M. (2016a). Halk bilgisinin takvim, mevsim/iklim, çevre, sağaltma ve hukuka dönük temsilleri. Halk bilimi el kitabı. (M. Aça, Ed.). Konya: Kömen.

Aça, M. (2016b). Denizin çocukları: Giresun ve Trabzon yöresi balıkçılarının meslek folkloru. Saarbrücken, Deutchland: Türkiye Âlim Kitapları.

Berkes, F. (1993). Traditional ecological knowledge in perspective. Traditional ecological knowledge: Concepts and cases. (Julian T. Inglis, Ed.). Ottawa: International Development Research Centre.

Berkes, F. (2008). Sacred ecology. New York: Routledge.

Brokensha, D. W., Warren, D. M. Werner, O. (Ed). (1980). Indigenous knowledge systems and development. Washington, DC: University Press of America.

Büyükşahin, F. (2017). Kültür-çevre bağlamında geleneksel ekolojik bilginin korunmasının önemi: Sarlkeçili Yörükler örneği. (Doktora Tezi). Ankara Üniversitesi Sosyal Bilimler Enstitüsü Sosyal Çevre Bilimleri Anabilim Dalı, Ankara.

Büyükşahin, F., Güneş, G. (2017). Pastoral göçebe toplumlar ve kültürel peyzaj korumanın önemi. JRTR, S. 4-1, ss. 36-48.

Ceríaco, L. MP., Marques, M. P., Madeira, N. C., Vila-Viçosa, C. M., Mendes, P. (2011). Folklore and traditional ecological knowledge of geckos in Southern Portugal: implications for conservation and science. Journal of Ethnobiology and Ethnomedicine, ss. 7-26.

Frazer, J. G. (2017). Psişik işler: Batıl inançlar kurumlarımızın gelişimini nasıl etkiledi? (İ. H. Yılmaz, Çev.). İstanbul: Pinhan.

Frazer, J. G. (2019). Ruhun tehlikeleri ve tabu. (İ. H. Yılmaz, Çev.). İstanbul: Pinhan.

Freeman, M. R. M., Carbyn, L. N. (Ed.). (1988). Traditional knowledge and renewable resource management in northern regions. Edmonton: University of Alberta.

Hardesty, D. L. (1977). Ecological anthropology. New York: Wiley.

Johannes, R. E. (1981). Words of the lagoon: Fishing and marine lore in the Paulau district of Micronesia. Berkeley: University of California.

Johnson, M. (Ed). (1992). Lore; capturing traditional environmental knowledge. Ottawa: Dene Cultural Institute, International Development Research Centre.

Karabaşa, S. (2018). Ankara ili Nallıhan ilçesi Yenice köyünde kültür-çevre ilişkileri üzerine etnografik bir değerlendirme. Doktora Tezi. Ankara Üniversitesi Sosyal Bilimler Enstitüsü Halkbilim Anabilim Dalı. 
Klee, G. A. (Ed). (1980). World systems of traditional resource management. London: Edward Arnold. Knudtson, P. and Suzuki, D. (1992). Wisdom of the elders. Toronto: Stoddart.

Lasserre, P. and Ruddle, K. (1983). Traditional knowledge and management of marine coastal systems. Paris: UNESCO.

Levi-Strauss, C. (2010). Yaban düşünce. (T. Yücel, Çev.). İstanbul: Yapı Kredi.

Mazzocchi, F. (2006). Western science and traditional knowledge. EMBO Reports, 7(5), pp. 463-466.

McNeely, J. A. and Pitt, D. (Ed). (1985). Culture and conservation. Dublin: Groom Helm.

Morauta, L., Pernetta, J. and Heaney, W. (Ed). (1982). Traditional conservation in Papua New Guinea: Implications for today. Port Moresby, Papua New Guinea: Institute of Applied Social and Economic Research.

Niamir, M. (1990). Herders' decision-making in natural resources management in Arid and Semiarid Africa. Community Forestry Note 4. Rome: FAO.

Özdemir, N. (2018). Geleneksel bilgi ve kültür ekonomisi. Türk Dünyası İncelemeleri Dergisi, S. 8/1, ss. $1-28$.

Posey, D. A. and Balee, W. (Ed). (1989). Resource management in Amazonia: Indigenous and folk strategies. New York: Advances in Economic Botany.

Ruddle, K. (1993). The transmission of traditional ecological knowledge. Traditional ecological knowledge: Concepts and cases. (Julian T. Inglis, Ed.) Ottawa: International Development Research Centre.

Ruddle, K. and Chesterfield, R. (1977). Education for traditional food procurement in the Orinoco Delta. Berkeley: University of California Press.

Ruddle, K. and Johannes, R. E. (Ed). (1989). Traditional marine resource management in the Pacific Basin: An anthology. Jakarta: UNESCO/RPSTSEA.

Semiz, Ö. (2015). Geleneksel bilgi, folklor ve fikri mülkiyet hukuku: Yerel kollektif bilginin hukuki korunması. Fikri Mülkiyet Hukuku Yıllı̆̆g-2013. (T. Memiş, Ed.). (ss. 376-402). Ankara: Yetkin.

Yolcu, M. A. (2018). Geleneksel ekolojik bilgi bağlamında Çanakkale halk botaniği. Çanakkale Araştırmaları Türk Yıllı̆̆gl, ss. 24, 63-77.

\section{Elektronik kaynaklar}

Büyükşahin, F., Güneş, G. (2016). Geleneksel ekolojik bilginin önemi: Sarıkeçili Yörükler örneği. Hacettepe Üniversitesi Sosyolojik Araştırma E-Dergisi. Erişim: 11.06.2019, www.sdergi.hacettepe. edu.tr/makaleler/FerhatBuyuksahinGulGunes.pdf 